\title{
Analýza vybraných morfologických charakteristik pro rybniční sítě ve čtyřech oblastech
}

\section{VÁCLAV DAVID, TEREZA DAVIDOVÁ}

Klíčová slova: historický rybník - krajina - hustota rybníků - fyzicko-geografické podmínky

\section{SOUHRN}

Rybníky jsou významnou organickou součástí krajiny České republiky již po staletí. Nachází se na většině území republiky a plní řadu funkcí kromě té historicky hlavní, kterou je chov ryb. Hustota rybníků a jejich vlastnosti jsou značně proměnlivé na rưzných místech republiky, což je ovlivněno mimo jiné přírodními podmínkami a historickým vývojem. Tento článek se zabývá porovnáním čtyř území, která byla vybrána pro zpracování prípadových studií pro potřeby výzkumného projektu DG16P02M036 Údržba, opravy a monitoring hrází historických rybníků jako našeho kulturního dědictví financovaného Ministerstvem kultury prostřednictvím programu NAKI II. Porovnání je zaměřeno především na hustotu a velikosti rybníků v oblasti Kostelecka, Blanicka, Blatenska a Třeboňska.

Výsledky analýz jednotlivých území provedených s ohledem na morfologické charakteristiky území a strukturu sítě rybníků ukazují značné odlišnosti mezi jednotlivými oblastmi. Jako ukazatele morfologie území byly použity průměrná nadmořská výška a průměrný sklon území, v prípadě rybníků se jednalo o hustotu rybníků, medián jejich velikosti a průměrnou velikost. Hodnoty morfologických ukazatelů a charakteristik rybníků byly vzájemně porovnány za účelem posouzení jejich závislosti. Výsledky ukazují vztah pouze v prípadě průměrné sklonitosti území a hustoty rybníků a jejich průměrnou velikostí. V obou prípadech se jedná o pokles, tj. s rostoucí sklonitostí klesá jak hustota rybníků, tak jejich velikost.

\section{ÚVOD}

Rybníky jsou již po staletí významným prvkem naší kulturní krajiny. Oplývá jimi značná část území naši republiky, přičemž tyto vodní nádrže plní řadu funkcí mimo té historicky nejvýznamnější, kterou je chov ryb. Hustota rybníků a jejich struktura s ohledem na velikost a další charakteristiky však mohou být velmi rozdílné prì porovnání území s odlišným historickým vývojem, prírodními podmínkami a dalšími faktory.

Význam rybníků je zmíněn již Karlem IV., který ve svém majestátu „Ut regnum nostrum Bohemiae piscinis et vaporibus abundaret..." citovaném mnohými autory (např. Janským [1]) zmiňuje nejen funkci produkční, ale i hydrologickou a klimatickou. Stejně tak byl význam rybníků a rybnikářství vyzdvihován i v pozdějších obdobích, na počátku 20. stol. např́klad Šustou a Mokrým [2], ze současných autorů se významu rybnikářství v minulosti i současnosti věnuje např́klad Hule [3].

Tento př́spěvek se zaměřuje na porovnání čtyř území, která byla zvolena pro prípadové studie pro potřeby projektu DG16P02M036 Údržba, opravy a monitoring hrází historických rybníků jako našeho kulturního dědictví řešeného v rámci programu NAKI II financovaného Ministerstvem kultury ČR. Porovnání je zaměřeno na strukturu a hustotu rybníků v jednotlivých oblastech, kterými jsou Kostelecko, Blanicko, Blatensko a Třeboňsko ve vztahu k fyzicko-geografickým charakteristikám těchto území. Analýzy jsou zaměřeny především na rybníky s rozlohou větší než 0,5 ha s prihlédnutím ke skutečnosti, zda se jedná o rybníky historické či vystavené v nedávné minulosti. V př́padě těchto rybníků byly provedeny analýzy se zaměřením na kategorie jejich velikosti v rámci jednotlivých oblastí.

\section{ZÁJMOVÉ OBLASTI}

Zájmové oblasti byly vymezeny s ohledem na hydrologické poměry, tj. jako povodí. Ve většině prípadů se jedná o jedno či více povodí definovaných jednoznačně uzávěrovým profilem, v jednom př́padě však bylo nutno území vymezit komplikovaněji. Oblasti byly vybírány tak, aby pokrývaly různé fyzicko-geografické podmínky s tím, aby se v nich vyskytovalo dostatečné množství historických rybníků. Umístění zájmových oblastí v rámci České republiky je znázorněno na obr. 1 .

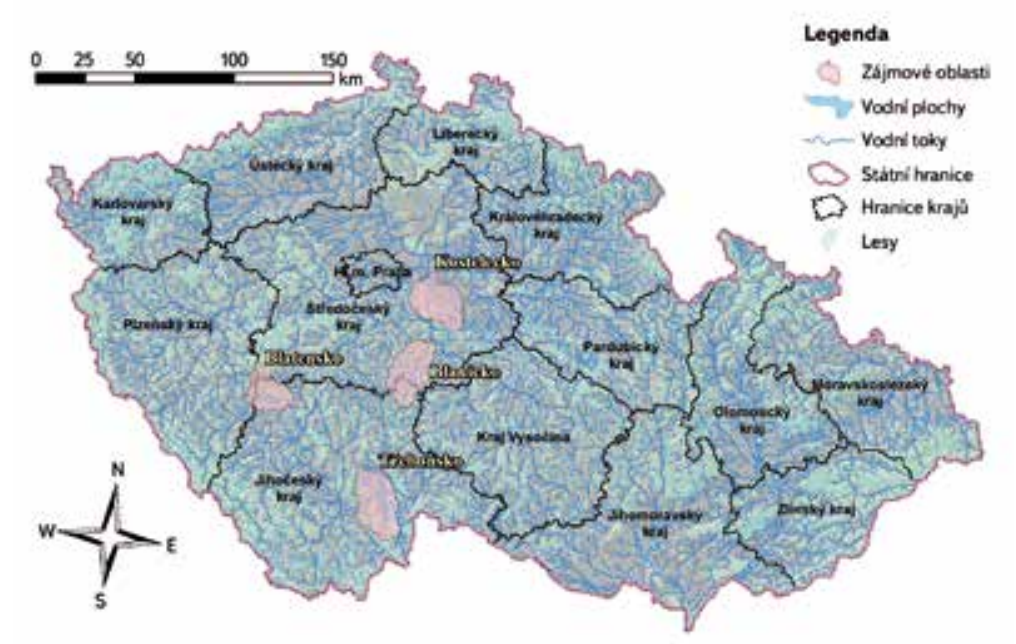

Obr. 1. Vymezení zájmových oblastí Fig. 1. Location of regions of interest 


\section{Kostelecko}

Tato oblast se nachází 35 km východně od Prahy ve Středočeském kraji. Zahrnuje povodí Jevanského a Nučického potoka po jejich soutok se Sázavou, povodi Šembery a Bylanky po jejich soutok a povodí Výrovky po soutok s Vrbčanským potokem. Celková rozloha této oblasti činí 533,3 km². Území je intenzivně zemědělsky využíváno zejména $\vee$ jeho východní části, v západní části jsou větši měrou zastoupeny lesní porosty. $V$ obou prípadech se jedná o poměrně rozsáhlé a značně souvislé celky. Největšími sídly jsou zde Kostelec nad Černými Lesy, Kouřim, která je historickým správním střediskem, Uhlírské Janovice a na severozápadním okraji zasahuje do oblasti Český Brod. Z geomorfologického hlediska spadá toto území do Hercynského systému (provincie Česká vysočina, subprovincie Česko-moravská soustava a Česká tabule).

\section{Blanicko}

Oblast Blanicka se rozprostírá kolem hory Blaník (632 m n. m.) cca 55 km jihovýchodně od Prahy a zasahuje jednak do Středočeského kraje a jednak do Jihočeského kraje. Představuje celé povodí toku Blanice (Vlašimské) po její soutok se Sázavou 2 km nad Českým Šternberkem. Celková rozloha povodí Blanice k uzávěrovému profilu činí 543,3 km². V území jsou významně zastoupeny jak plochy zemědělské půdy, tak lesní porosty, obojí rozptýlené v menších plochách. Hlavními sídly území jsou Vlašim, Načeradec, Divišov a Postupice. Geomorfologicky náleží oblast Blanicka k Hercynskému systému (provincie Česká vysočina, subprovincie Česko-moravská soustava).

\section{Blatensko}

Tato oblast je pro daný účel definována povodím Lomnice po soutok se Skalicí. Oblast se nachází 80 km jihozápadně od Prahy na rozhraní tři krajů - Jihočeského, Plzeňského a Středočeského. Celková rozloha oblasti činí $394,6 \mathrm{~km}^{2}$. V území jsou zastoupeny jak lesní porosty, které jsou soustředěny především v severní a jižní části území, tak zemědělská půda, významnou krajinnou složkou jsou zde ovšem právě i rybníky. Hlavní sídla v tomto území představují Blatná, Kasejovice, Mirotice a Bělčice. Oblast Blatenska spadá geomorfologicky do Hercynského systému (provincie Česká vysočina, subprovincie Česko-moravská soustava a částečně Poberounská soustava).

\section{Třeboňsko}

Území se nachází 120 km jižně od Prahy na území Jihočeského kraje a předsta-

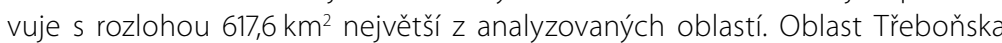
je $v$ tomto prípadě prostorově vymezena jako část povodí Lužnice po soutok s Nežárkou. Oproti hranicím hydrologických povodí je oddělena plocha na pravém břehu Lužnice v úseku od Suchdola nad Lužnicí po oddělení Nové řeky, území na pravém břehu Nové řeky a celá horní část povodí Lužnice k Suchdolu nad Lužnicí. Oblast je hojně pokryta lesními porosty včetně lužních lesů, nejdůležitější roli na značné části tohoto území však hrají rybníky. Geomorfologicky je i oblast Třeboňska součástí Hercynského systému (provincie Česká vysočina, subprovincie Česko-moravská soustava a velmi okrajově Šumavská soustava).

\section{ANALÝZY OBLASTÍ}

V prvním kroku byly provedeny analýzy jednotlivých oblastí s ohledem na jejich morfologii, a to na základě předpokladu, že morfologie území je jedním z důležitých faktorů hrajících v minulosti roli při výběru lokalit pro výstavbu rybníků. Z tohoto pohledu byly posuzovány nadmořské výšky jednotlivých oblastí a jejich sklonitost. Následně byla provedena statistická analýza velikosti rybníků $\checkmark$ jednotlivých oblastech a identifikace těch, které existovaly již v první polovině 19. stol. a byly větší než 0,5 ha.

\section{Morfologie oblastí}

Analýza morfologie terénu v jednotlivých oblastech byla provedena s využitím nejpodrobnějších dostupných výškopisných dat poskytovaných ČúZK. Jedná se o digitální model reliéfu 5. generace, což je podklad s vysokou přesností a velkou podrobností [4]. Nejprve byly stanoveny základní charakteristiky nadmořské výšky jednotlivých oblastí. Jednalo se o minimální a maximální výšku a o průměrnou nadmořskou výšku jednotlivých oblastí.

Dalším krokem bylo posouzení sklonitostních charakteristik území. K tomuto účelu byl proveden výpočet sklonů v každé z oblastí s využitím modelu terénu převzorkovaného na rozlišení $10 \times 10 \mathrm{~m}$. V prípadě sklonů byla určena jeho průměrná hodnota. Morfologické ukazatele jednotlivých oblastí jsou uvedeny v tabulce 1 .

Tabulka 1. Morfologické ukazatele jednotlivých oblastí Table 1. Morphological properties of regions of interest

\begin{tabular}{|c|c|c|c|c|}
\hline Oblast & $\begin{array}{l}\text { Minimální } \\
\text { nadmořská } \\
\text { výška } \\
(\mathrm{m} \mathrm{n} . \mathrm{m} .)\end{array}$ & $\begin{array}{l}\text { Maximální } \\
\text { nadmořská } \\
\text { výška } \\
(\mathrm{m} \text { n. m.) }\end{array}$ & $\begin{array}{l}\text { Průměrná } \\
\text { nadmořská } \\
\text { výška } \\
(\mathrm{m} \text { n. m.) }\end{array}$ & $\begin{array}{l}\text { Průměrný } \\
\text { sklon } \\
(\%)\end{array}$ \\
\hline Kostelecko & 163,9 & 556,9 & 352,5 & 7,4 \\
\hline Blanicko & 304,6 & 723,9 & 480,5 & 9,9 \\
\hline Blatensko & 357,2 & 827,1 & 509,4 & 6,6 \\
\hline Třeboňsko & 406,9 & 569,9 & 456,2 & 2,6 \\
\hline
\end{tabular}

Výsledky této základní analýzy ukazují, že nejvýše položenou oblastí je Blatensko (průměrná nadmořská výška 509,4 m n. m.), zatímco nejníže položenou je Kostelecko (prưměrná nadmořská výška 352,5 m n. m.). Naproti tomu nejplošším územím je Třeboňsko (průměrný sklon 2,6 \%) a nejsvažitějším Blanicko (průměrný sklon 9,9\%).

\section{Struktura rybníků v jednotlivých oblastech}

Pro potřeby hodnocení rybníků v jednotlivých oblastech byla použita prostorová vektorová data dostupná v databázi DIBAVOD - vrstva A05_vodni_ nadrze [5]. V první řadě byla provedena analýza rybníků s ohledem na jejich velikost. $Z$ tohoto pohledu byly rybníky a vodní plochy zatříděny do kategorií 0-0,5 ha, 0,5-1 ha, 1-2 ha, 2-5 ha, 5-10 ha, 10-50 ha a více než 50 ha. Podle předpokladu byla nejčetněji zastoupena kategorie do 0,5 ha, která zahrnuje i malé návesní nádrže a ostatní drobné vodní plochy z pohledu rybnikářství a rybníků pouze málo významné. Nejvyšší zastoupení těchto malých vodních ploch vykazuje oblast Blanicka, kde vodní plochy menší než 0,5 ha představují 


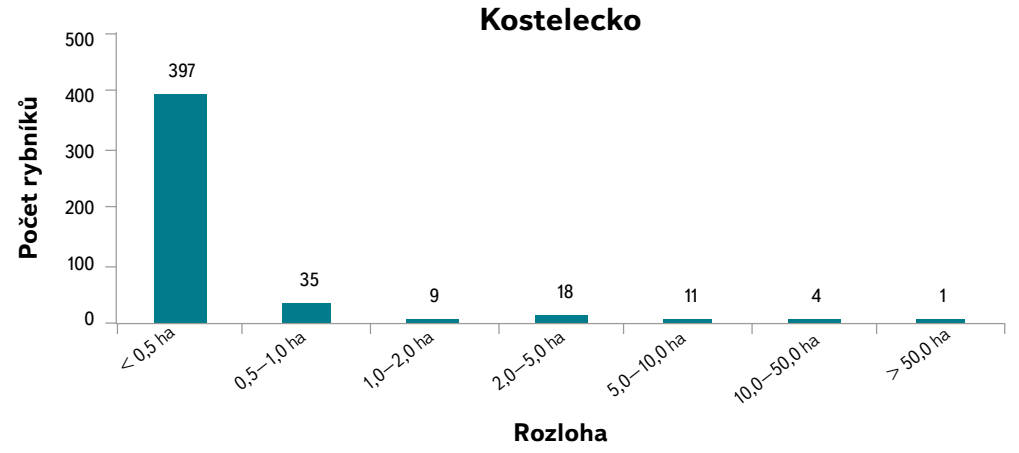

Obr. 2. Počty rybníků v jednotlivých velikostních kategoriích v oblasti Kostelecka Fig. 2. Frequencies of fishponds in size categories in the region Kostelecko

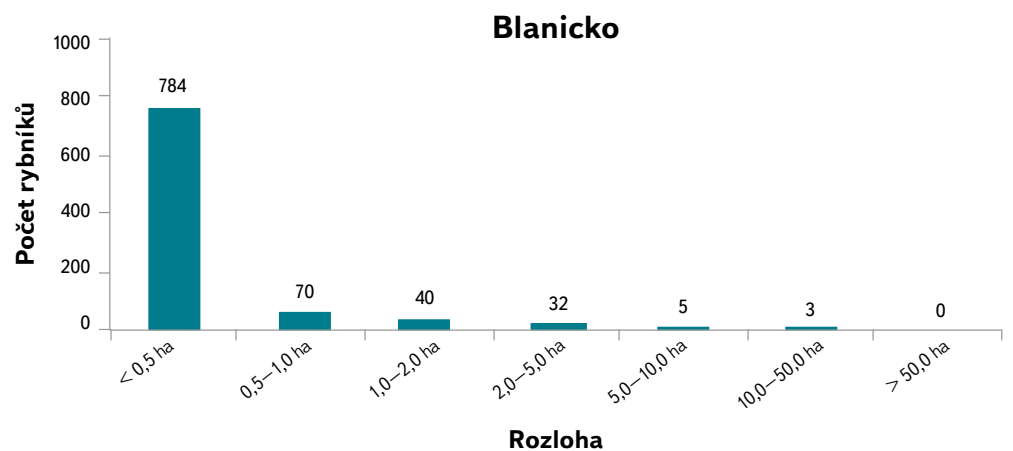

Obr. 3. Počty rybníků v jednotlivých velikostních kategoriích v oblasti Blanicka Fig. 3. Frequencies of fishponds in size categories in the region Blanicko

$23 \%$ celkové současné rozlohy vodních ploch, v ostatních prípadech se jedná o $10 \%$ (Kostelecko) či mnohem méně (4 \% pro Blatensko a $1 \%$ pro Třeboňsko). Zastoupení uvedených velikostních kategorií v jednotlivých oblastech je znázorněno $v$ grafech na obr. 2 až 5 a v tabulce 2.

Dalšími ukazateli velikosti rybníků, které byly určeny, byla maximální velikost (velikost největší vodní plochy/rybníka) a medián velikosti pro soubory rybníků s rozlohou nad 0,5 ha. V prrípadě první oblasti (Kostelecko) je největší

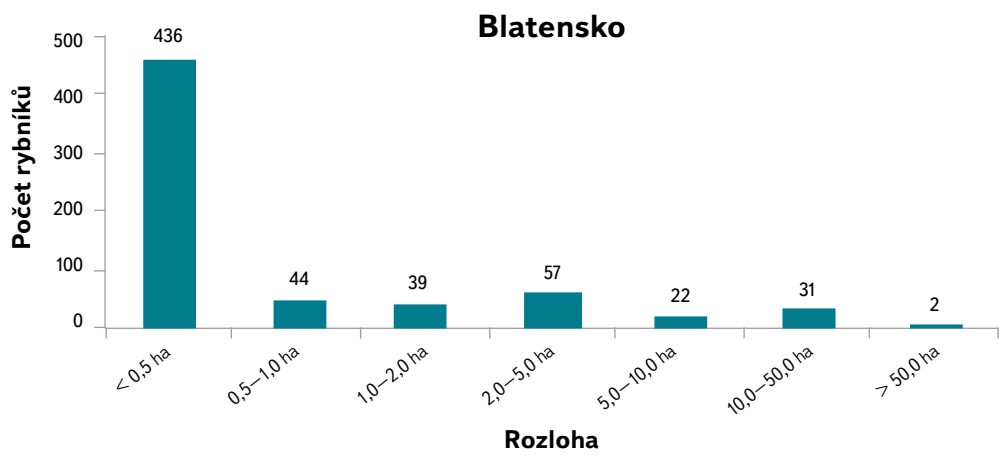

Obr. 4. Počty rybníků v jednotlivých velikostních kategoriích v oblasti Blatenska Fig. 4. Frequencies of fishponds in size categories in the region Blatensko

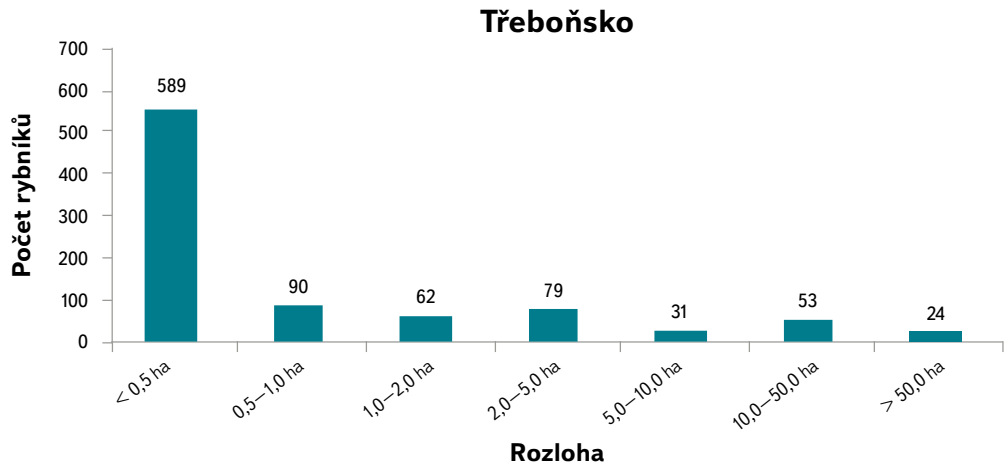

Obr. 5. Počty rybníků v jednotlivých velikostních kategoriích v oblasti Třeboňska Fig. 5. Frequencies of fishponds in size categories in the region Třeboňsko

vodní plochou Vavřinecký rybník z roku 1472 s výměrou 77,9 ha. Medián velikosti rybníků nad 0,5 ha činí v prípadě Kostelecka 1,37 ha. V prípadě druhé oblasti (Blanicko) je největší vodní plochou rybník Smikov, který se nachází na toku Chotýšanky, s rozlohou 23,2 ha. V oblasti Blanicka dosahuje hodnota mediánu 1,10 ha. Na Blatensku je největším rybníkem Labutz založeným v roce 1492 [6] s rozlohou 101 ha. Hodnota mediánu v tomto prípadě činí 2,90 ha. Na Třeboňsku se nachází největší rybníky ze všech analyzovaných oblastí, celkem 77 z nich má rozlohu větší než 10 ha.

Tabulka 2. Zastoupení velikostnich kategorií rybnikü a vodních ploch v jednotlivých oblastech

Table 2. Frequencies of fishponds and water bodies in size categories in regions of interest

\begin{tabular}{|c|c|c|c|c|c|c|c|c|}
\hline \multicolumn{3}{|c|}{ Kostelecko } & \multicolumn{2}{|c|}{ Blanicko } & \multicolumn{2}{|c|}{ Blatensko } & \multicolumn{2}{|c|}{ Třeboňsko } \\
\hline Velikost (ha) & Počet & Výměra (ha) & Počet & Výměra (ha) & Počet & Výměra (ha) & Počet & Výměra (ha) \\
\hline$<0,5$ & 397 & 37,3 & 784 & 85,8 & 436 & 57,3 & 589 & 70,7 \\
\hline $0,5-1$ & 35 & 24,7 & 70 & 47,7 & 44 & 31,7 & 90 & 64 \\
\hline $1-2$ & 9 & 12,5 & 40 & 54,2 & 39 & 57,2 & 62 & 90,8 \\
\hline $2-5$ & 18 & 60,6 & 32 & 101 & 57 & 197,5 & 79 & 254,8 \\
\hline $5-10$ & 11 & 77,1 & 5 & 37 & 22 & 161,1 & 31 & 214,4 \\
\hline $10-50$ & 4 & 75,9 & 3 & 47,1 & 31 & 679,6 & 53 & 1057 \\
\hline$>\mathbf{5 0}$ & 1 & 77,9 & 0 & 0 & 2 & 152,5 & 24 & 3438,5 \\
\hline
\end{tabular}




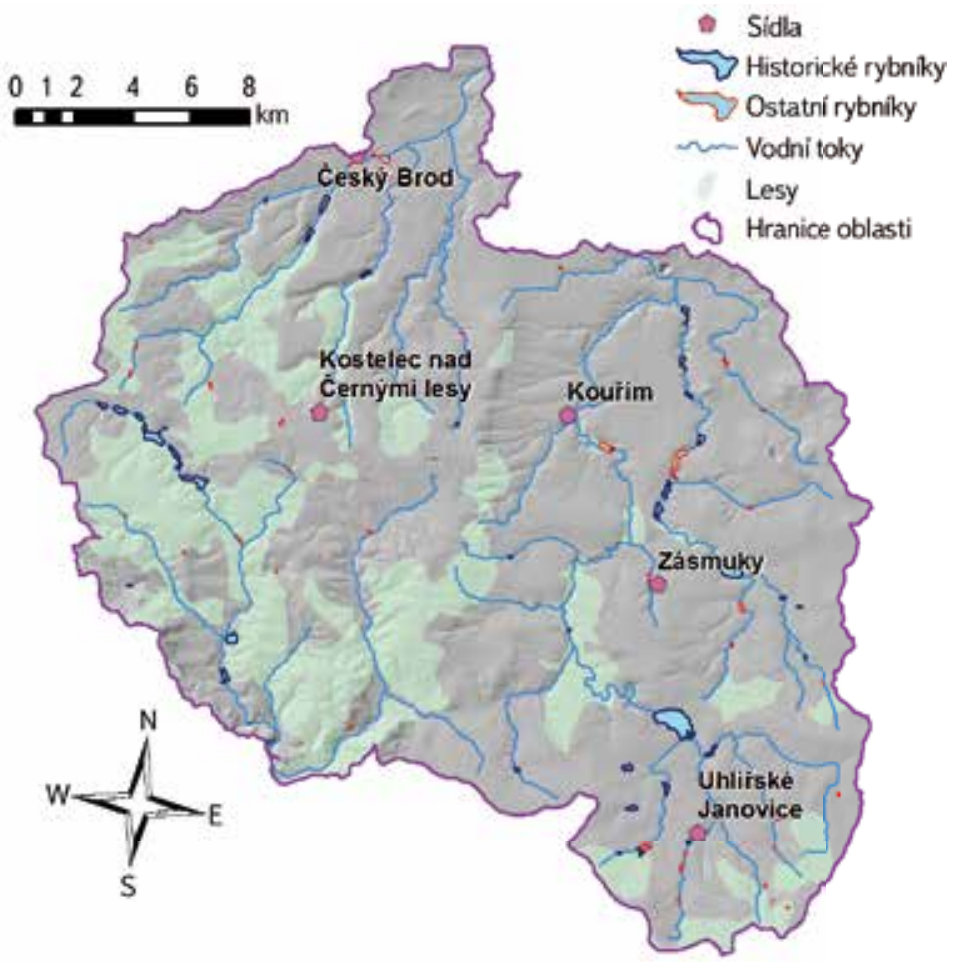

Obr. 6. Mapa zachycující rybníky v oblasti Kostelecka s rozlišením rybníků historických a ostatních

Fig. 6. Map showing fishponds in the region Kostelecko distinguishing those historical and others

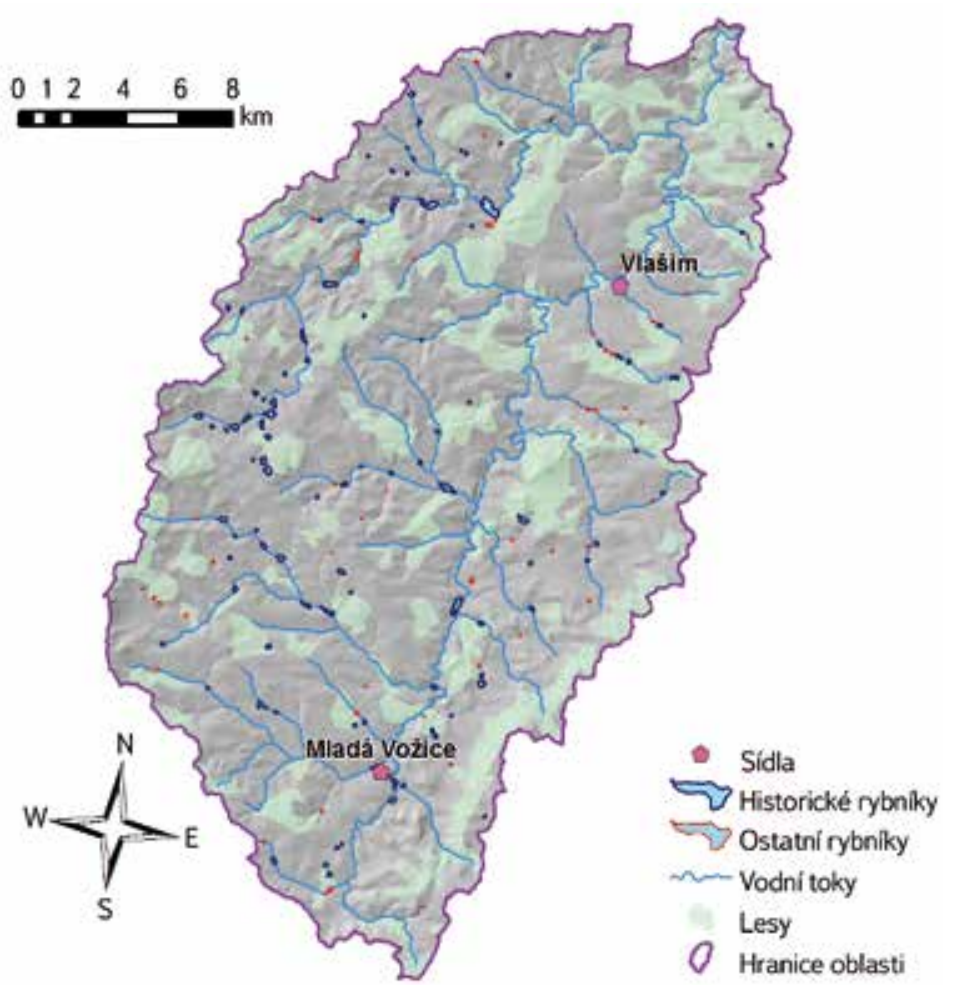

Obr. 7. Mapa zachycující rybníky v oblasti Blanicka s rozlišením rybníků historických a ostatnich

Fig. 7. Map showing fishponds in the region Blanicko distinguishing those historical and others

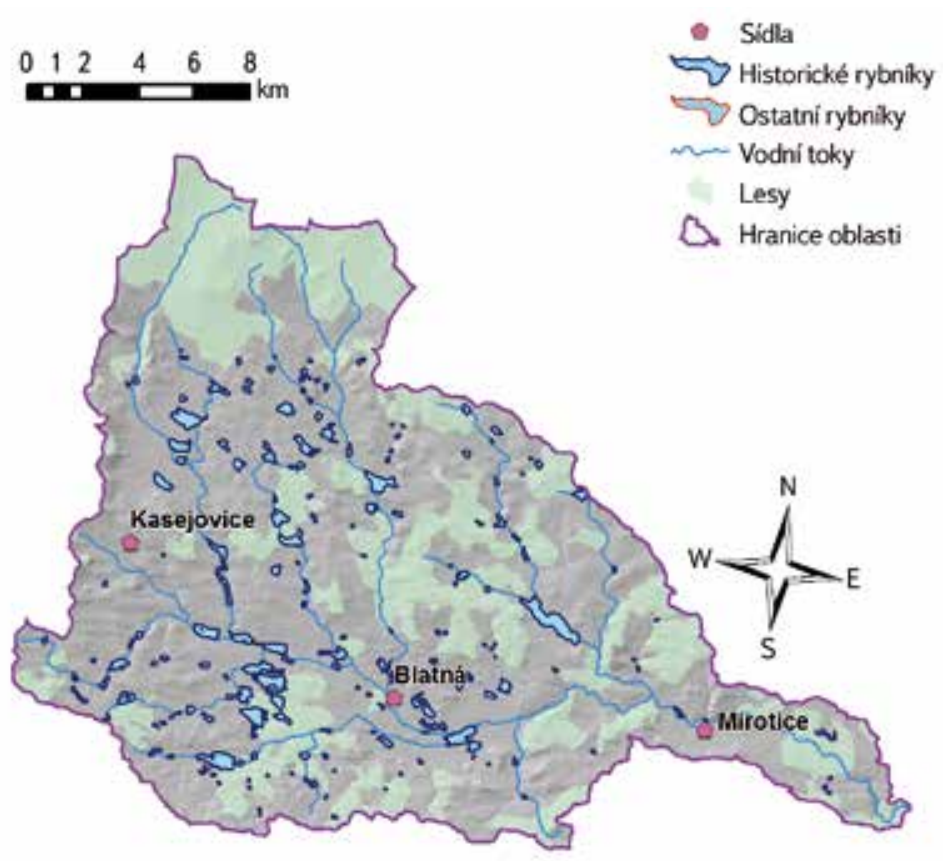

Obr. 8. Mapa zachycující rybníky v oblasti Blatenska s rozlišením rybníků historických a ostatních

Fig. 8. Map showing fishponds in the region Blatensko distinguishing those historical and others

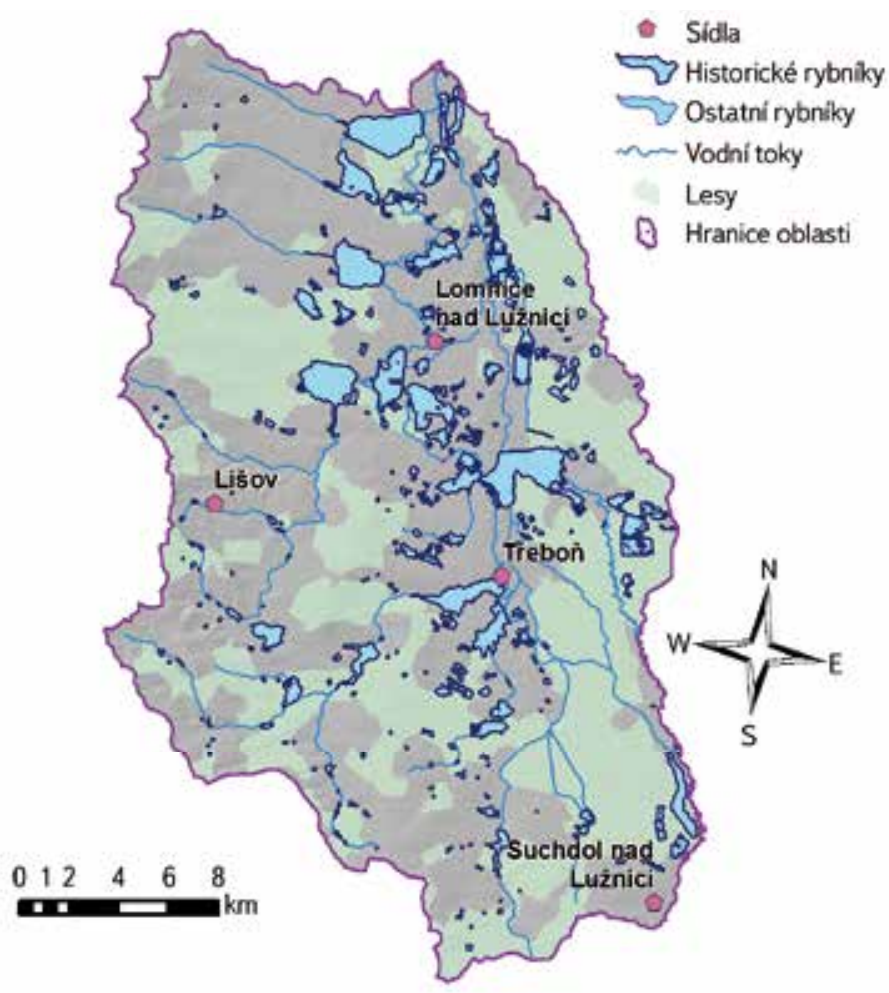

Obr. 9. Mapa zachycující rybníky v oblasti Třeboňska s rozlišením rybníků historických a ostatních

Fig. 9. Map showing fishponds in the region Třeboňsko distinguishing those historical and others 


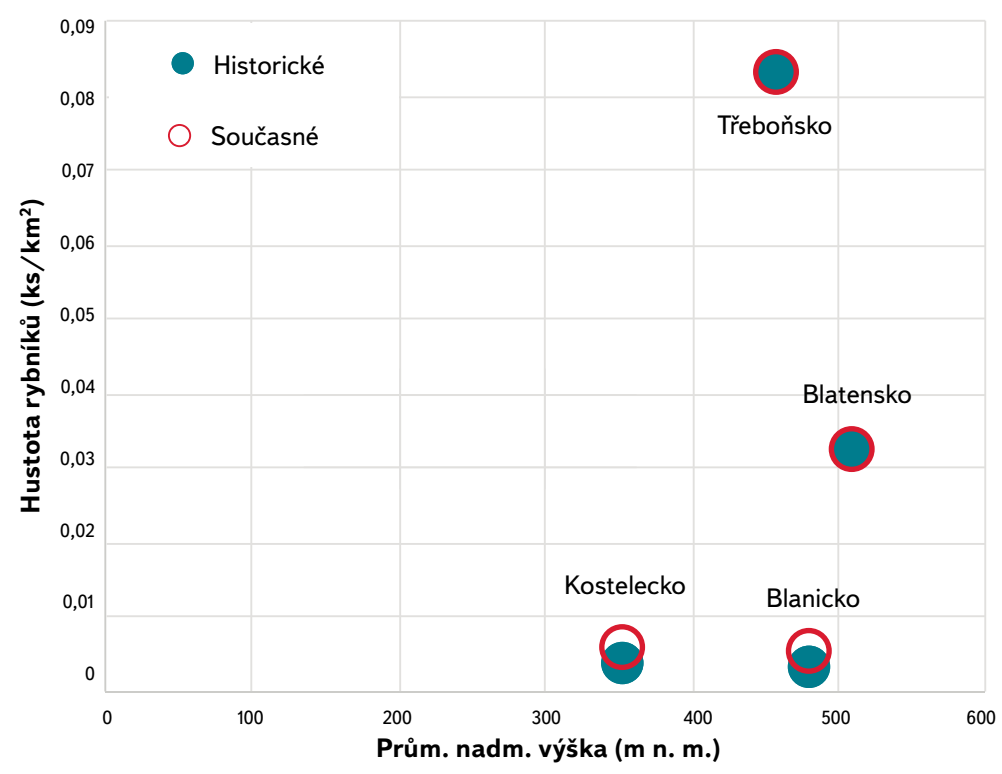

Obr. 10. Vztah mezi průměrnou nadmořskou výškou (m n. m.) a hustotou rybníků větších než 0,5 ha $\left(\mathrm{ks} . \mathrm{km}^{-2}\right)$

Fig. 10. The relationship between average elevation ( $m$ a.s.I.) and density of fishponds larger than 0.5 ha $\left(\right.$ pcs. $\left.\mathrm{km}^{-2}\right)$

Největším z nich je rybník Rožmberk založený v roce 1584 [6], který je s rozlohou 427,1 ha i největším rybníkem České republiky, byṫ v minulosti se ještě větší rybníky (Čeperka a Blato) nacházely v Polabí [7]. Medián velikosti rybníků větších než 0,5 ha v tomto prípadě dosahuje hodnoty 2,51 ha.

Dalším krokem byla s ohledem na zaměření projektu, pro jehož potřeby byly analýzy zpracovány, identifikace těch rybníků, které lze považovat za historické. V tomto prípadě byly jako historické označeny ty, které jsou zaznamenány již na mapách II. vojenského mapování. Ty jsou nejstarším mapovým podkladem, který má dostatečnou polohovou presnost a podrobnost a pokrývá celé území České republiky. Starší mapy, např́klad mapy I. vojenského mapování, mají k danému účelu nedostatečnou polohovou přesnost [8]. K analýzám byla využita digitalizovaná vrstva vodních ploch zachycených na těchto mapách [9].

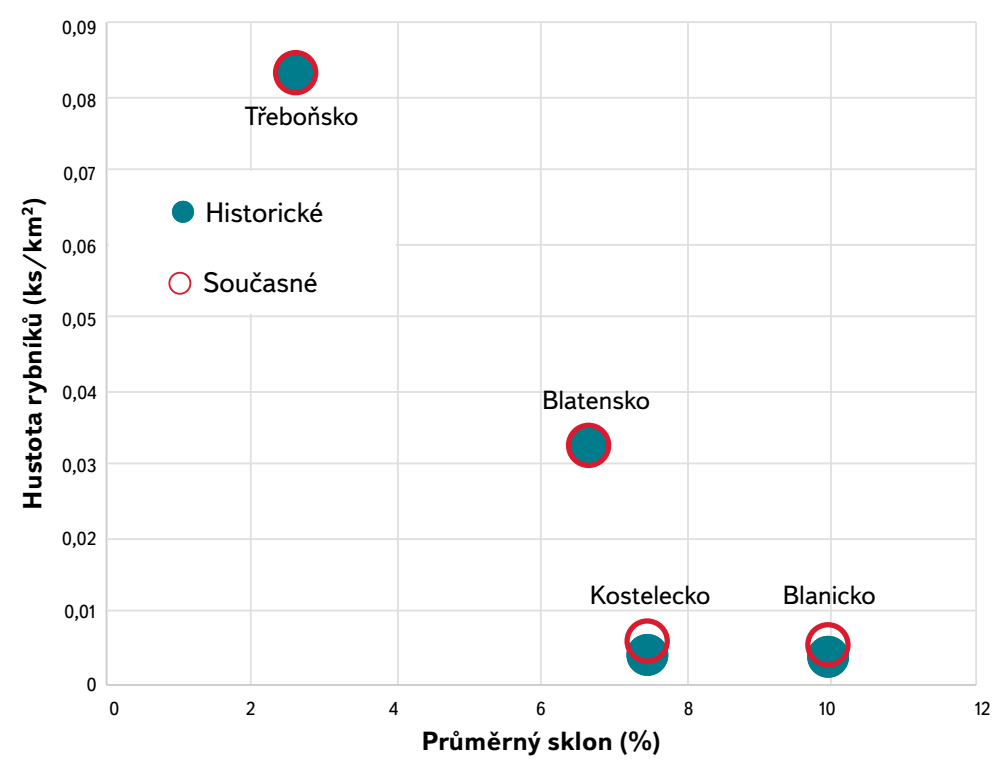

Obr. 11. Vztah mezi průměrnou sklonitostí (\%) a hustotou rybníků větších než 0,5 ha ( $\left(\mathrm{ks} . \mathrm{km}^{-2}\right)$ Fig. 11. The relationship between average slope (\%) and density of fishponds larger than 0.5 ha $\left(\right.$ pcs. $\left.\mathrm{km}^{-2}\right)$

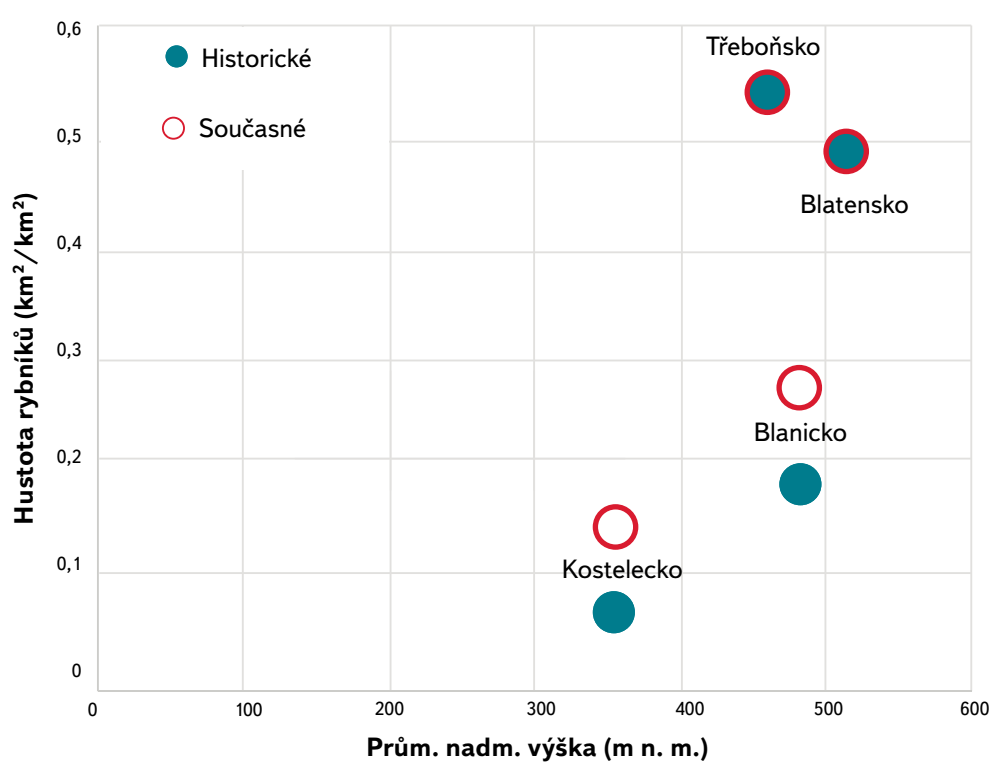

Obr. 12. Vztah mezi průměrnou nadmořskou výškou ( $m$ n. m.) a hustotou rybníků větších než 0,5 ha $\left(\mathrm{km}^{2} \cdot \mathrm{km}^{-2}\right)$

Fig. 12. The relationship between average elevation ( $m$ a.s.l.) and density of fishponds larger than $0.5 \mathrm{ha}\left(\mathrm{km}^{2} . \mathrm{km}^{-2}\right)$

Vrstva obsahuje pouze vodní plochy s rozlohou nad 0,5 ha, jelikož menší vodní plochy vykazují značné odchylky v poloze, které vylučují jejich automatizované zpracování v prostředí GIS. Historické rybníky byly identifikovány tak, že současná vrstva vodních ploch byla překryta vrstvou historických rybníků a byly z ní vybrány ty, které protínaly některý z historických rybníků.

S ohledem na zastoupení historických rybníků vykazují jednotlivé oblasti značné odlišnosti. Zatímco v prípadě Třeboňska a Blatenska spadají všechny vodní plochy s rozlohou větší než 0,5 ha mezi historické, na Kostelecku a Blanicku jich je významné množství mladších než cca 160 let. Konkrétně se jedná o přibližně polovinu nádrží v případě Kostelecka a třetinu nádrží v prrípadě Blanicka. Mapy prezentující vodní nádrže v jednotlivých oblastech včetně rozdělení na historické a ostatní jsou znázorněny na obr. 2.

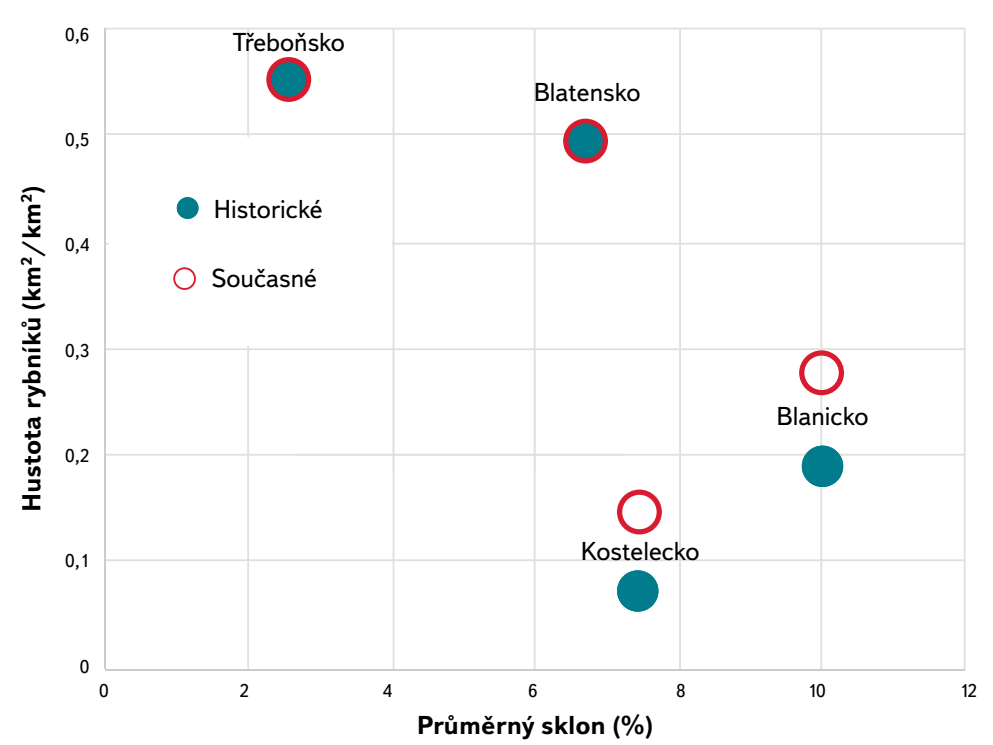

Obr. 13. Vztah mezi průměrnou sklonitostí (\%) a hustotou rybníků větších než 0,5 ha $\left(\mathrm{km}^{2} . \mathrm{km}^{-2}\right)$ Fig. 13. The relationship between average slope (\%) and density of fishponds larger than 0.5 ha $\left(\mathrm{km}^{2} . \mathrm{km}^{-2}\right)$ 


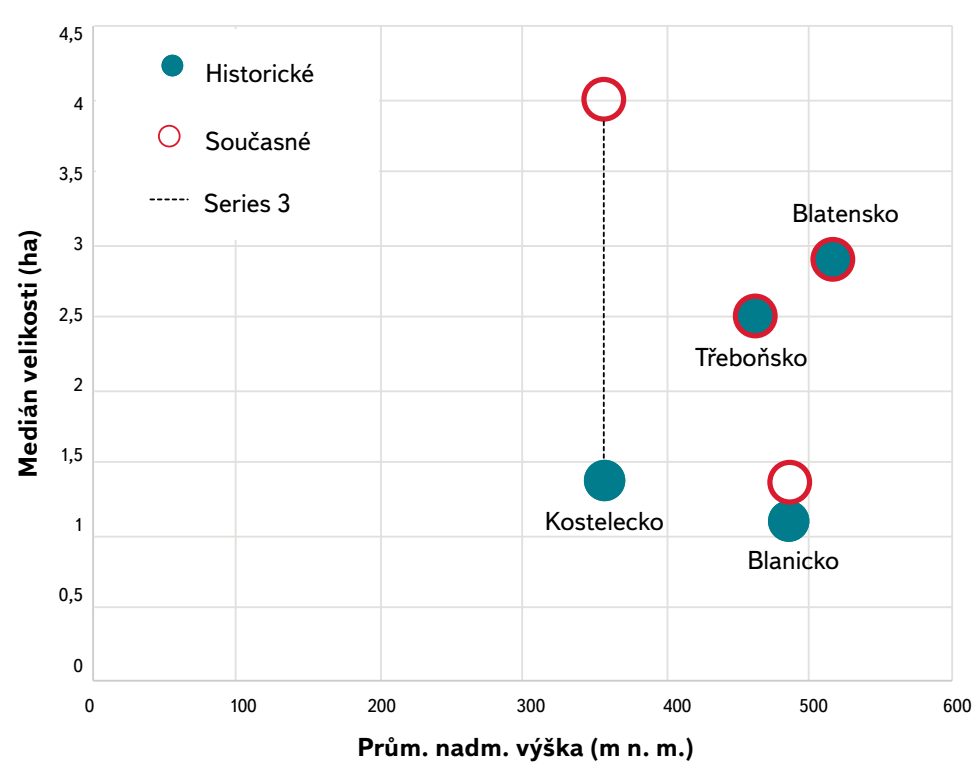

Obr. 14. Vztah mezi prưměrnou nadmořskou výškou ( $m$ n. m.) a mediánem velikosti rybníků větších než 0,5 ha (ha)

Fig. 14. The relationship between average elevation ( $m$ a.s.l.) and median of fishponds areas larger than 0.5 ha (ha)

\section{HODNOCENÍ}

Posuzované oblasti vykazují s ohledem na strukturu rybníků a vodních nádrží značné odlišnosti. Při konfrontaci struktury sítě vodních nádrží s morfologickými ukazateli je zřejmé, že s narůstající sklonitostí území se obecně zmenšuje velikost vodních nádrží i jejich celkové množství a celková rozloha při uvažování vodních ploch s rozlohou nad 0,5 ha. Největší rybníky se tak nachází na Třeboňsku (Rožmberk, Horusický rybník, Dvořiště a další, tedy rybníky, které patří k největším v celé České republice [10]), které vykazuje nejnižší hodnotu průměrného sklonu, stejně tak tato oblast vykazuje největší počet rybníkư i největší celkovou rozlohu vodních ploch. Celkově menší rybníky se pak nachází v oblastech s vyššími hodnotami průměrného sklonu (Kostelecko, Blanicko). Naopak jako málo významnou

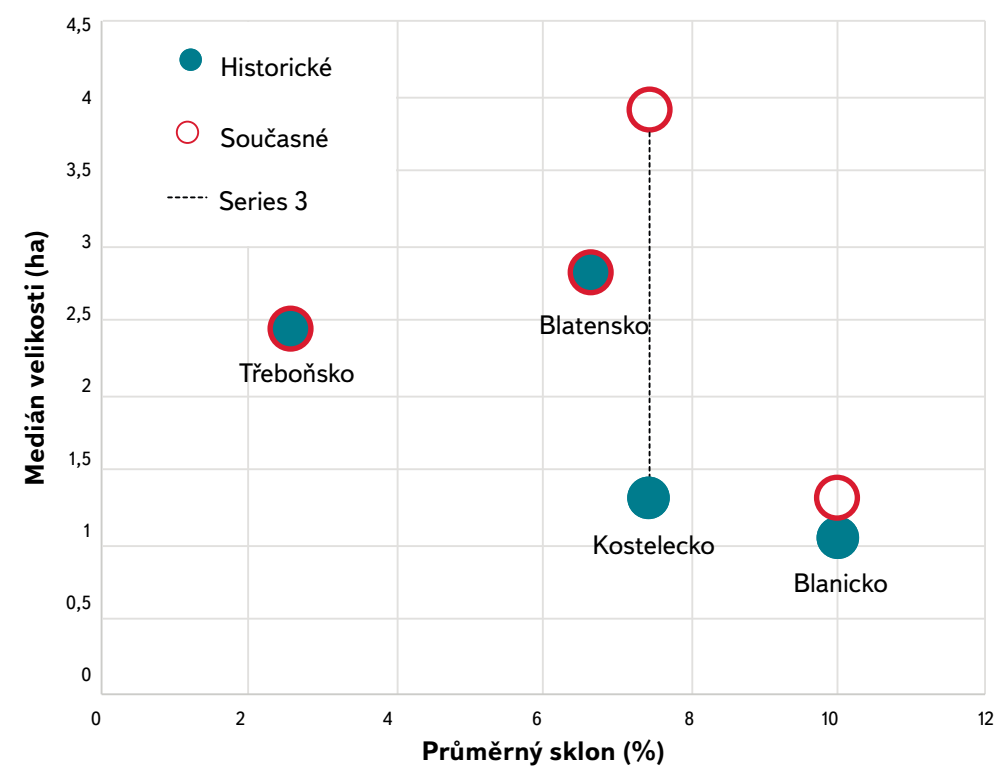

Obr. 15. Vztah mezi průměrnou sklonitostí (\%) a mediánem velikosti rybníků větších než 0,5 ha (ha) Fig. 15. The relationship between average slope (\%) and median of fishponds areas larger than 0.5 ha (ha)

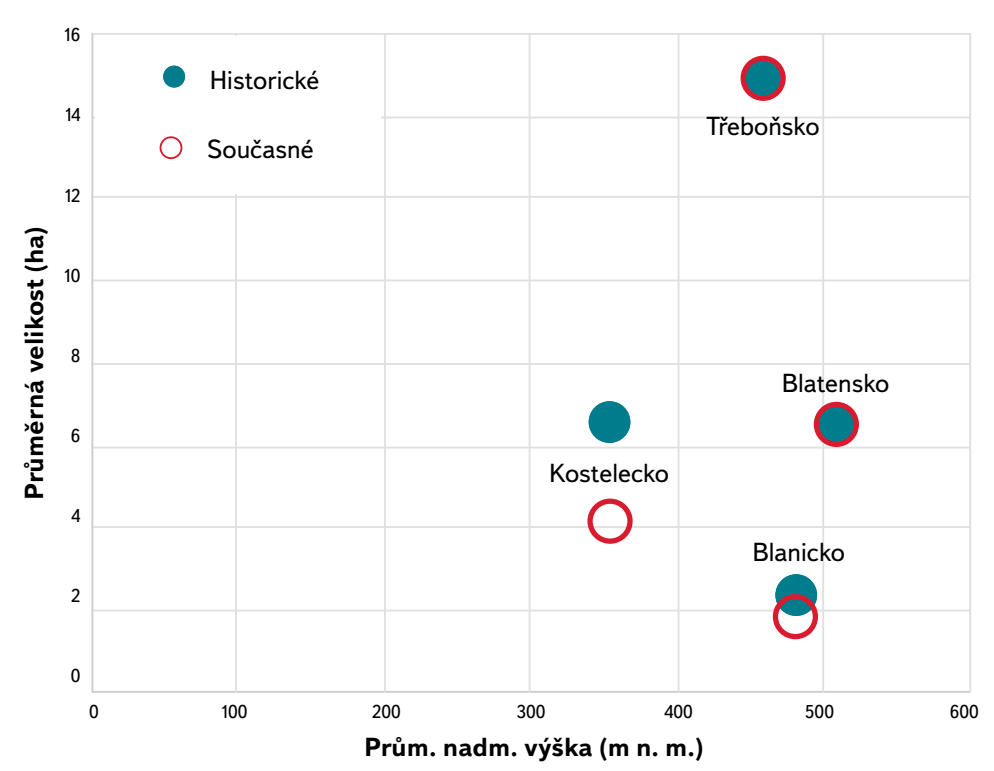

Obr. 16. Vztah mezi průměrnou nadmořskou výškou ( $m$ n. m.) a průměrnou velikostí rybníků větších než 0,5 ha (ha)

Fig. 16. The relationship between average elevation ( $m$ a.s.l.) and average area of fishponds larger than 0.5 ha (ha)

Ize považovat nadmořskou výšku jednotlivých oblastí, jelikož Kostelecko s nejnižší průměrnou nadmořskou výškou se vyznačuje nízkým množstvím rybníků a jejich relativně malou rozlohou, zatímco Třeboňsko s druhou nejnižší průměrnou nadmořskou výškou je v tomto ohledu na opačném pólu.

Pro potřeby podrobnějšího hodnocení byly vypočteny hustoty vodních ploch nad 0,5 ha vyjádřené jednak jako procentuální zastoupení vodních ploch $v$ jednotlivých oblastech $\left(\mathrm{km}^{2} \cdot \mathrm{km}^{-2}\right)$ a jednak jako počet vodních ploch na jednotku plochy $\left(\mathrm{ks}_{\mathrm{k}} \mathrm{km}^{-2}\right)$. I v prípadě těchto ukazatelů se vyznačuje největším zastoupením rybníků a vodních nádrží nad 0,5 ha Třeboňsko s hodnotami $0,083 \mathrm{~km}^{2} . \mathrm{km}^{-2}$ a $0,55 \mathrm{ks} \cdot \mathrm{km}^{-2}$. Poměrně vysoké hodnoty odpovídaji i oblasti Blatenska - 0,032 $\mathrm{km}^{2} \cdot \mathrm{km}^{-2}$ a 0,49 ks. $\mathrm{km}^{-2}$. Na opačném pólu se nachází oblasti Kostelecka a Blanicka s hodnotami 0,006 a 0,005 km². $\mathrm{km}^{-2}$ a 0,15 a $0,28 \mathrm{ks} \cdot \mathrm{km}^{-2}$.

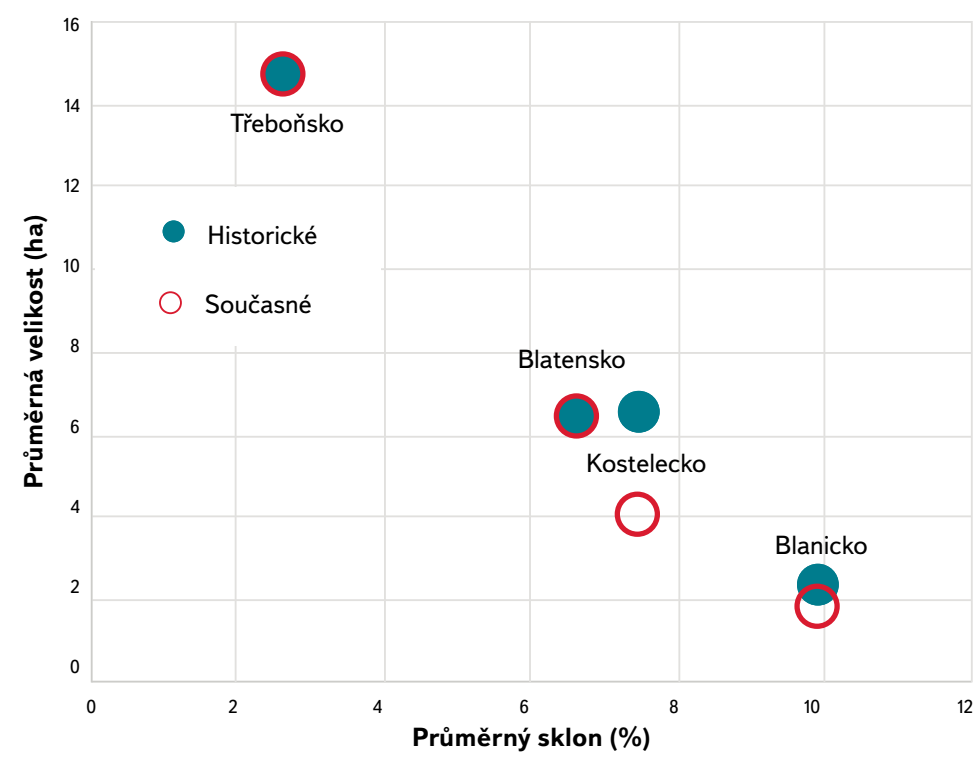

Obr. 17. Vztah mezi průměrnou sklonitostí (\%) a průměrnou velikostí rybníků větších než 0,5 ha (ha) Fig. 17. The relationship between average slope (\%) and average area of fishponds larger than 0.5 ha (ha) 
Pro potřeby podrobnějšího posouzení vztahu mezi morfologickými ukazateli a strukturou rybníků v jednotlivých oblastech bylo zpracováno grafické znázornění jejich hodnot, a to jak pro rybníky historické, tak pro ty současné. Pro posouzení byly jako charakteristiky popisující morfologii zvoleny průměrná nadmořská výška a průměrný sklon, pro rybníky pak hustota vodních ploch a hodnota mediánu a průměru velikost rybníků s rozlohou nad 0,5 ha. Tyto hodnoty jsou znázorněny v grafech na obr. 10 až 17. Z grafického znázornění je patrné, že ve většině prípadů neexistuje významný vztah mezi porovnávanými ukazateli. Výjimku tvoří vztah mezi hustotou rybníků $v \mathrm{ks} \mathrm{km}^{-2}$ a průměrnou sklonitostí oblasti a průměrnou velikostí rybníků a průměrnou sklonitostí. V obou těchto prípadech je patrný nárůst hustoty rybníků a jejich průměrné velikosti s klesající průměrnou sklonitostí. To naznačuje, že rybníky byly budovány spíše v plošších územích a že v těchto územích byly stavěny rybníky s větší výměrou.

Za pozornost stojí dále skutečnost, že v prípadě oblastí s vysokou hustotou vodních ploch (Blatensko a Třeboňsko) jsou všechny nádrže nad 0,5 ha starší než cca 160 let a že se zde tedy nenachází žádné relativně nové nádrže. To Ize chápat především tak, že s ohledem na vysokou hustotu vodních ploch $\checkmark$ těchto územích jednak nebyl prostor a vhodné profily pro budování nových a jednak nebyla potřeba budovat další nádrže.

\section{ZÁVĚR}

Prezentované oblasti byly voleny tak, aby reprezentovaly území s odlišnými charakteristikami. Předmětem analýzy byl historický vývoj, morfologie terénu a samotná struktura sítě vodních nádrží v řešeném území. Výsledky ukazují, že vytipované oblasti jsou vhodné pro další řešení projektu, jelikož jsou výrazně odlišné vzhledem k uvažovaným charakteristikám. Liší se jak strukturou rybniční sítě, tak morfologickými charakteristikami. V případě morfologických charakteristik se ukazuje zejména závislost mezi sklonitostí terénu v oblasti a hustotou vodních ploch. Ta má podobu klesající hustoty vodních ploch s narůstající sklonitostí. Stejně tak výsledky naznačují nárůst velikosti vodních ploch s klesajícím průměrným sklonem. Obojí patrně souvisí s tím, že historicky byly rybníky zakládány v plochých podmáčených oblastech, jelikož zejména mělké rybníky byly vhodné pro teplovodní chov ryb. Naopak v prípadě dalších posuzovaných kombinací ukazatelů se závislost neukazuje.

$\checkmark$ prípadě hodnocených oblastí byl odlišný i jejich historický vývoj, který však bude nutno podrobně posoudit na základě studia historických map i dostupných písemných pramenů. Prvotní analýzy však ukazují, že v oblastech s vysokou hustotou vodních ploch se v podstatě nevyskytují žádné novodobé vodní nádrže. $V$ dalších krocích budou zkoumány mimo jiné vlastnosti hrázových těles a podrobný historický vývoj množství vodních ploch v jednotlivých oblastech s využitím mapových a dalších podkladů zachycujících období starší než v prípadě druhého vojenského mapování, tedy první poloviny 19. stol. To však bude představovat značný objem manuální práce vzhledem ke skutečnosti, že starší mapové podklady nemají dostatečnou polohovou přesnost. S ohledem na zaměěení projektu, v jehož rámci byly prezentované analýzy provedeny, je však znalost historického kontextu nezbytná. Péče o hráze historických rybníků je velmi náročná a znalost období jejich vzniku umožňuje jednak identifikaci těch nejcennějších a jednak pomáhá, při znalosti vývoje technologií stavby rybníků v minulosti, zvolit vhodný prístup k péči či postup opravy.

Navazující výzkum bude též zahrnovat rozšiření hodnocení na více oblastí s cílem získat větší soubor, s jehož využitím by bylo možno provést hodnocení struktury rybníků $v$ širším měřítku. To může dále sloužit jako podklad pro identifikaci území, v nichž je žádoucí nádrže obnovovat či nově budovat. Pokud se pak ukáží některé charakteristiky území jako významně determinující některé charakteristiky rybníků a vodních nádrží, Ize výsledky získané popsaným postupem využít pro potřeby formulace doporučení pro výstavbu nových nádrží.

\section{Literatura}

[1] JANSKÝ, B. Mladotický rybník - historie a současnost. In: Rybníky 2016. Praha: Česká technika nakladatelství ČVUT, 2016, s. 41-53. ISBN 978-80-01-05978-4.

[2] ŠUSTA, V. a MOKRÝ, T. Význam jihočeského rybnikářství: Jeho vznik a vývoj. Praha: Československá akademie zemědělská, 1931.

[3] URBÁNEK, M., ed. Naše rybářství. České Budějovice: TYP, 2015. ISBN 978-80-87699-05-8.

[4] BRÁZDIL, K., ed. Technická zpráva k digitálnímu modelu reliéfu 5. generace (DMR5G). In: K. BRÁZDIL, ed. Geoportál ČUZZK [online]. Praha: Zeměměřický úřad a Vojenský geografický a hydrometeorologický úřad, 2015 [cit. 04. záŕí 2016]. Dostupné z: http://geoportal.cuzk.cz/Dokumenty/TECHNICKA ZPRAVA_DMR_5G.pdf

[5] ZBOŘIL, A. Digitální báze vodohospodářských dat - DIBAVOD. In: Hydroekologický informačnísystém VÚV TGM [online]. Praha: Výzkumný ústav vodohospodářský T. G. Masaryka, 2005 [cit. 04. záŕí 2016] Dostupné z: http://heis.vuv.cz/informace/cojeto/VUV_DIBAVOD.pdf

[6] KOUTEK, T. Nejkrásnějši českérybnikky. B.m.: Brána, 2008. ISBN 978-80-7243-376-6.

[7] LIEBSCHER, P. Ryby, rybniky, rybníkári: [historie a tradice rybníkářstvív Čechách]. Ostrava: Matúšek, 2010 ISBN 978-80-254-8246-9.

[8] CAJTHAML, J. a KREJČl, J.Využití starých map pro výzkum krajiny. In: Sborníkz 15. ročníku mezinárodního sympozia GIS Ostrava 2008. Ostrava: TANGER, spol. s r. o., 2008. ISBN 978-80-254-1340-1.

[9] PAVELKOVÁ, R., FRAJER, J., HAVLÍČEK, M., et al. Historical ponds of the Czech Republic: an example of the interpretation of historic maps: an example of the interpretation of historic maps. Journal of Maps [online]. 2016/07/12, p. 1-9. ISSN 1744-5647. Dostupné z: doi:10.1080/17445647.2016.1203830

[10] LIEBSCHER, P. a RENDEK, J. Rybníky České republiky. Praha: Academia, 2014. Průvodce (Academia). ISBN 978-80-200-2368-1.

\section{Poděkování}

Výsledky prezentované $v$ tomto príspěvku byly dosaženy $v$ rámci řešení výzkumného projektu DG16P02M036 Údržba, opravy a monitoring hrází historických rybníků jako našeho kulturního dědictví rešeného v rámci programu NAKI II financovaného Ministerstvem kultury $\check{R}$.

\section{Autoři}

Ing. Václav David, Ph.D.

凶vaclav.david@fsv.cvut.cz

Ing. Tereza Davidová, Ph.D.

$凶$ tereza.davidova@fsv.cvut.cz

České vysoké učení technické v Praze, Fakulta stavební, Katedra hydromeliorací a krajinného inženýrství

Příspěvek prošel lektorským řízením. 
